\title{
Managerial conservatism, board independence and corporate innovation
}

Jun Lu

Wei Wang

Cleveland State University, w.wang24@csuohio.edu

Follow this and additional works at: https://engagedscholarship.csuohio.edu/bus_facpub

Part of the Corporate Finance Commons, and the Finance and Financial Management Commons How does access to this work benefit you? Let us know!

\section{Publisher's Statement}

NOTICE: this is the author's version of a work that was accepted for publication in . Changes resulting from the publishing process, such as peer review, editing, corrections, structural formatting, and other quality control mechanisms may not be reflected in this document. Changes may have been made to this work since it was submitted for publication. A definitive version was subsequently published in Journal of Corporate Finance, 48, (2018), doi:10.1016/ j.jcorpfin.2017.10.016

\section{Recommended Citation}

Lu, Jun and Wang, Wei, "Managerial conservatism, board independence and corporate innovation" (2018). Business Faculty Publications. 284.

https://engagedscholarship.csuohio.edu/bus_facpub/284

This Article is brought to you for free and open access by the Monte Ahuja College of Business at EngagedScholarship@CSU. It has been accepted for inclusion in Business Faculty Publications by an authorized administrator of EngagedScholarship@CSU. For more information, please contact library.es@csuohio.edu. 


\title{
Managerial conservatism, board independence and corporate innovation
}

\author{
Jun Lu Wei Wang
}

A R T I C L E I N F O

O31Keywords:

Innovation

Board independence

Outside director

Endogeneity

Difference-in-difference

Sox

\begin{abstract}
A B S T R A C T
Using panel data on U.S. public firms, we document a positive effect of board independence on corporate innovation. This effect is concentrated in firms that are larger in size, in the nontechnical industries, facing less product market competition, and using more debt, where managers are more likely to be excessively risk averse. We establish causality of board independence on innovation using a difference-in-difference approach that exploits an exogenous shock to board composition, namely, the mandate of a majority of outside directors on company boards by NYSE and NASDAQ in response to the passage of Sarbanes-Oxley Act in 2002. We further examine incentive compensation as a possible mechanism. We show that firms with more independent boards use more equity-based compensation, especially stock options, to promote managerial risk-taking.
\end{abstract}

\section{Introduction}

Innovation is widely viewed as a critical driving force of economic growth (e.g., Romer, 1990; Segerstrom, 1991). Innovation at the firm level is constrained by an agency problem that derives from the discrepant attitudes toward risk between the managers of a company and its shareholders, often known as managerial conservatism. Managers, whose personal wealth disproportionately hinges on the performance of the firm they run, tend to prefer projects with less volatile cash flows to reduce the risk of compromising their wealth or losing their jobs (Jensen and Meckling, 1976; Amihud and Lev, 1981; Smith and Stulz, 1985; Hirshleifer and Thakor, 1992; Gormley and Matsa, 2016). They hence have little incentive to innovate because innovation is a generally very risky endeavor (Holmstrom, 1989). Well-diversified shareholders, in contrast, tend to prefer risky projects because the value of their stockholdings increases with the riskiness of cash flows of the company they invest in, due to the option-like property of equity investments. To promote innovation, it is essential to overcome this conflict of interests.

An independent board, with a majority of outside directors, is a major governance mechanism designed to mitigate conflicts of interest between managers and shareholders. The literature has shown that outside directors are active monitors and play a role

We would like to thank Sanjai Bhagat, and Xuan Tian for valuable discussions on an early draft of this paper, Ron Masulis, and Yongxian Tan for helpful comments, brownbag seminar participants at the Central University of Finance and Economics, participants at the 2014 International Conference on Corporate Finance and Capital Market, and participants at the 2016 Great China Finance Conference and the discussant James Qiancheng Zhen. 
in curtailing managerial pursuit of private benefits and encouraging efforts (e.g., Brickley and James, 1987; Duchin et al., 2010; Wintoki et al., 2012; Schwartz-Ziv and Weisbach, 2012; Knyazeva et al., 2013). There is little evidence, however, about whether an independent board is also effective in aligning the risk preference of the managers with shareholders and hence ameliorating the managerial tendency to underinvest in innovation. In this paper we attempt to fill this gap.

Unlike most other types of agency problems, managerial conservatism is a "hidden, silent killer" that is very difficult to discern as "the dangers of playing it safe aren't sudden, obvious, and dramatic" (Sundheim, 2013, pp. 5-6). When it comes to investment decisions, managers have the power to decide whether to invest in routine projects or risky innovative projects. If the manager is risk averse, he or she may intentionally avoid those risky investments, leading to lower innovation output. ${ }^{1}$ One solution, as suggested by Holmstrom (1989), is to provide incentives to managers to take more risk. We contend that the board of directors has the tools and capacity to incentivize managerial risk-taking. ${ }^{2}$ Previous literature has shown that equity compensation, especially stock options, is used to induce efforts as well as risk-taking (e.g., Core and Guay, 1999; Coles et al., 2006). In modern corporations, the decision of how to compensate the managers is delegated to the board of directors. The board is hence able to combat managerial conservatism by designing a compensation package that features greater equity stakes.

To the extent that the effectiveness of a board is contingent on its independence, we hypothesize that a board with more outside directors is more likely to encourage managerial risk-taking. This predicts an overall positive relationship between board independence and corporate innovation. We expect this positive relationship is more pronounced in firms where managers are more likely to be excessively risk averse, such as at large firms, firms in traditional industries (vis-à-vis high-tech firms), firms in non-competitive industries and firms with high leverage. Small firms, high-tech firms, and firms in competitive product markets (e.g., Hart, 1983; Karuna, 2007) have to innovate to survive and succeed, and their CEOs thus have greater incentives to take risk and invest in innovation. In big, conventional firms and firms facing low competition, managers could avoid risk-taking without alarming shareholders, and hence an independent board matters more for this type of firms. In addition, high financial leverage gives rise to high firm risk and exacerbates managerial conservatism (e.g., Hirshleifer and Thakor, 1992; Brisker and Wang, 2016). Therefore, an independent board is likely more effective in addressing underinvestment in innovation for highly-levered firms.

As discussed above, a channel through which a board combats managerial conservatism is executive compensation. We further hypothesize that boards with more independent directors are associated with greater equity compensation for the firm's CEO. What is more, because stock options provide convex payoffs which reward managers for the upsides and protect managers for the downsides, we expect that more independent boards are associated with more option-based compensation in particular.

To empirically test these hypotheses, we assemble a sample of panel data on U.S. public firms during the period of 1996 to 2007. Following the literature, we measure board independence as the fraction of outside directors on the board with a higher fraction representing greater independence. We measure firms' innovation mainly based on the outputs, i.e., the number of patents and citations, but also examine innovation inputs proxied by R\&D expenditures. Our results point to an overall positive association between board independence and innovation in the full sample. Our subsample analysis reveals differential impacts of board independence in the sense that the positive relationship is concentrated in firms that are larger in size; in traditional, lesscompetitive industries; and firms with greater leverage, indicating that independent boards make a difference where risk-taking is a scarcer resource.

The empirical assessment of whether board independence affects innovation is complicated by the standard endogeneity problem that arises because the observed variation in board independence may merely be a manifestation of managerial entrenchment (Hermalin and Weisbach, 1998). We address this concern using a difference-in-difference (DiD) framework that exploits an exogenous variation in board composition caused by the new listing requirements of the NYSE and NASDAQ in 2003. As a response to the sweeping governance reforms of the Sarbanes-Oxley Act (SOX) of 2002, the exchanges mandated a majority of independent directors for all firms listed, leading to an exogenous increase over time in board independence for some firms. ${ }^{3} \mathrm{The}$ DiD approach essentially compares the innovative outputs before and after the forced increase in the fraction of outside directors with those not affected by the requirements acting as a control group. The DiD results in both the full sample and the Propensity Score matched sample confirm a positive relationship between board independence and innovation.

To identify the mechanisms through which an independent board exerts its impact on innovation, we examine CEOs' overall equity-type compensation and find that firms with more independent boards provide more equity-based compensation, and in particular option-based compensation, to their CEOs, consistent with independent boards promoting managerial risk-taking.

This paper is closely related to the contemporaneous work of Balsmeier et al. (2017). Balsmeier et al. (2017) document that increased monitoring by outside directors enhances exploitative innovation that leads to incremental improvements in products and services but not explorative innovation that leads to breakthroughs. An interpretation they give is managers want to take actions to produce quantifiable results that are visible to the board yet avoid being penalized for bad outcomes of the most risky, explorative innovation endeavor. Different from Balsmeier et al. (2017), we focus on whether and how a board aligns the risk preference of managers with those of shareholders. Few would deny that explorative innovation incurs more risk; but

\footnotetext{
${ }^{1}$ Lu and Wang (2015) develop a parsimonious model to show that managerial risk-aversion leads to underinvestment in research and development.

2 Boards of directors are delegated to risk oversight. For instance, Moody's views a board of directors' risk oversight role as "critical to the sound running of an institution", and one of the board's "central functions" with respect to risk are to "approve the firm's risk appetite as a component of its strategy". Some financial, energy and technology companies have set up separate risk committees on their boards. In addition, some recent evidence has shown that board composition affects firms' risk taking. For instance, Bernile et al. (2016) show a more diverse board foster more efficient rislk-taling, with more investments in R\&D and improved innovation outputs.

${ }^{3}$ See http://www.nyse.com/pdfs/finalcorpgovrules.pdf. Papers that exploit natural experiments brought about by Sox to address the endogeneity issue include Chhaochharia and Grinstein (2009), and Duchin et al. (2010).
} 
"exploitative" innovation endeavor represents considerable risk-taking, too, considering managers could easily choose a project with stable cash flows and take even less risks (e.g., replacement of worn-out equipment to continue current operation). We view an increase in overall innovation as the result of board of directors combating managerial conservatism, and our subsample evidence as well as the investigation of CEO equity compensation supports this view. Our findings hence provide an alternative explanation for the association between board independence and increase in innovation, and complement Balsmeier et al. (2017) in regard to the board's impact on managerial risk-taking. In addition, the differential impacts of board independence on innovation we've documented echo the message of Coles et al. (2008), who suggests that there does not exist an optimal board structure that fits all types of firms.

The rest of the paper is organized as follows: Section 2 provides a review of the related literature; Section 3 shows basic empirical results; Section 4 addresses the endogeneity issue and establishes causality; Section 5 investigates mechanisms; Section 6 concludes.

\section{Literature review}

Our research complements the burgeoning literature on the governance of innovation. Aghion et al. (2013) find that high institutional ownership is associated with more innovation after controlling for possible endogeneity issues. They interpret this result as being consistent with the career concern hypothesis: managers dislike risk innovation involves, but institutional investors can insulate them from being fired in case the innovation project fails for pure stochastic reasons and thus boost their incentives to "swing for the fences". Becker-Blease (2011) shows that greater protection from takeover provisions (measured as the G-index) is positively associated with innovation efforts and this result is driven by those provisions that the officers and directors actively adopted. In contrast, Atanassov (2013) documents that by exploiting an exogenous variation in corporate governance caused by the passage of state anti-takeover laws, when managers are protected from the threat of takeover, innovation productivity is reduced. In a recent cross-country study, Brown et al. (2013) show that strong shareholder protection and better access to stock market financing lead to substantially higher long-run rates of R\&D investment, particularly in small firms.

Our paper is also related to literature on board composition. Despite a strong push toward smaller and outsider-dominated boards from both regulators and institutions, Coles et al. (2008) contend that such a board composition may not be beneficial for all types of firms. They argue that complex firms - such as those that are large and diversified - have more advising needs and thus should have a large board with more outside directors, because outside directors possess rich industry experiences and can provide valuable advice to the firm. In contrast, R\&D intensive firms should have a large representation of inside directors on the board because they possess firm - specific knowledge that is vital for the firm to survive in an uncertain and competitive environment. Their empirical work generally supports these conjectures. In particular, they found that in complex firms, Tobin's $Q$ is increasing in board size and this relationship is driven by outside directors. In R\&D intensive firms, Tobin's $Q$ is increasing in the proportion of inside directors. Our finding that greater board independence helps innovation for only large firms and non-technical firms reinforces Coles et al.'s (2008) main idea that "one size does not fit all".

Lastly, our research is broadly linked to studies on the association between board independence and firm value because innovation is one important channel through which the firm gains a competitive advantage. The effect of board independence on firm value has been studied extensively, and the results, however, are inconclusive. Baysinger and Butler (1985) report that the proportion of outside directors in 1970 positively correlates with 1980 industry-adjusted return on equity. Hermalin and Weisbach (1991), however, find no significant same-year correlation between board composition and various measures of corporate performance. Similarly, Bhagat and Black (2001) find there is no correlation between board independence and firm performance in the long run. In an attempt to reconcile these mixed results, Duchin et al. (2010) hold that the effect of board independence on firm value depends on the magnitude of information costs. The recent work by Knyazeva et al. (2013), however, suggests there is a significant impact of board independence on firm value when the endogeneity of board independence is adequately controlled for.

\section{Empirical tests}

\subsection{Sample and variables}

Following the recent literature on innovation (e.g., Hirshleifer et al., 2013; Aghion et al., 2013), we measure innovation using patents and patent citations. The data are from the United States Patent and Trademark Office (USPTO) and compiled by Kogan et al. (2012) for the years1926 to 2010 (henceforth referred to as the KPSS patent data). It provides, among other items, annual records of both the citing and cited patent number, the date when the patent application is filed and the date when the patent is issued, and more importantly, the firm identifier ("permno"), which allows us to merge this data with stock information from the Center for Research in Security Prices (CRSP) and financial information from Compustat. ${ }^{4}$ The patent classification information is obtained from Google. We use it to benchmark a specific patent against others in the same patent class. ${ }^{5}$

\footnotetext{
${ }^{4}$ See https://iu.app.box.com/patentsfor detailed description of this dataset. This KPSS patent data has obvious advantages over the NBER patent data. It covers longer periods and as Kogan et al. (2012) put it: "we are able to provide some additions and corrections to the NBER data during the period of overlap with our data."

5 See https:/www.google.com/googlebools/uspto-patents-class.html for patent classification.
} 
We measure board independence as the fraction of outside directors on the board (e.g., Hermalin and Weisbach, 1991; Coles et al., 2008). The data are from RiskMetrics, which provides detailed information on board composition such as each director's classification (i.e., inside, outside or affiliated directors, and how they are defined), and composition of committees (e.g., nominating, compensation, and auditing) for the S\&P 1500 firms. Firms' financial data such as total assets, sales, leverage and R\&D expenditure are from Compustat. Our sample period is from 1996 to 2007. It starts in 1996 because that is the first year when the governance data is available in the RiskMetrics database; it ends in 2007 instead of 2010 because the patent data for the last three years are heavily truncated due to the time lag between the year when a patent application is filed and the year when it appears in the data. ${ }^{6}$ After merging board data from RiskMetrics and financial data from Compustat, our primary sample has 6275 firm-year observations, although the sample size varies for different investigations depending on the availability of data for specific variables used.

The KPSS patent database provides both the year when a patent application is submitted and the year it is approved. Following the literature, we use the patent application year in our analysis as it is closer to the creation of the actual innovation. We measure innovation in three ways. The first is the number of adjusted patents. Because the propensity to patent an innovation differs across patent classes, we scale each patent by a factor that is equal to the reciprocal of the total number of patents in the same three-digit patent class in the same year, and then sum them up. To account for quality of patents, we use patent citations as the second measure of innovation, which is computed as dividing the number of citations that each patent receives in subsequent years (up to 2010) by the total number of citations received for all patents in the same patent class in the same year, and then summing then up for all the patents a firm receives in the year. It is worth noting that this adjusting procedure for citations is especially important as a patent can keep receiving citations over a long period of time. A patent could have more citations not because it is more influential but because it appears earlier and have more time to receive citations. Our adjusting procedure controls for this time-fixed effect. We follow Trajtenberg (1990) to construct our third innovation measure as citation-weighted patents (Pat_cite). This measure uses a linear weighting scheme and is expressed as follows:

$$
\text { Pat_cite } e_{i t}=\sum_{i=1}^{n_{t}}\left(1+C_{i}\right)
$$

where $n_{t}$ is the number of patents issued in year $t$, and $C_{i}$ is the number of citations a patent receives in subsequent years.

We control for R\&D expenditure to capture the level of input in innovative activities. While one tends to presume more input should lead to more output, the actual relationship between R\&D and patents is not clear due to the agency problem between manager and shareholders (Jensen, 1993). Following the literature, we replace this variable with zero if it is missing. Other control variables include capital expenditure, board size and institutional ownership. Capital expenditures may affect innovation in two ways. On one hand, capital expenditures may compete with R\&D for budgets in a financially-constrained firm; thus if a firm allocates a big portion of available funds to capital investments, less will be available for R\&D projects, which reduces innovation. On the other hand, R\&D projects often are accompanied by a large investment in physical assets such as the supporting lab equipment and facilities, leading to a positive association between capital investments and innovation. Directors could lose incentive to monitor and advise the management as board size gets large (Yermack, 1996). Equity ownership by CEOs aligns their interests with those of shareholders, and thus may positively affect innovation. Institutional investors may provide protection for managers, making them more willing to take risk (Aghion et al., 2013). In addition to the above discussed variables, we also include other standard firm attributes including return on assets, book leverage, and firm size. Appendix A provides definitions of these variables.

\subsection{Summary statistics}

Table 1 reports the summary statistics of main variables. The number of adjusted patents (Patents) ranges from 0 to 1.876 , with a mean of 0.087 and a standard deviation of 0.184 . The number of adjusted citations (Citations) range from 0 to 1.867 and citation-weighted patents (Pat_cite) ranges from 0 to 2.445. The fairly large range and standard deviation suggest a considerable variation in innovation across firms and over time. All three measures are highly skewed, with the median value being significantly smaller than the mean. To mitigate the effect of skewness on the regression estimates, we use the natural logarithm transformation of patents as our dependent variables (e.g., $\ln (1+$ patents)). The main explanatory variable, the fraction of outside directors (Outdir) for an average firm-year is $69 \%$, ranging from 0 to $100 \%$. A typical board has about 9 directors and the number of directors ranges from 5 to 16 . Institutional investors on average hold $66 \%$ of firm's common shares. A median firm has 1.5 billion dollars of assets, spends $\$ 38$ million on R\&D. Its book leverage, ROA and asset tangibility average $0.199,0.159$, and 0.282 , respectively. All these statistics are consistent with existing literature.

\footnotetext{
${ }^{6}$ The average time lag is about two years. This means that there are an unknown number of patent applications in 2009 and 2010 that are still being evaluated by the patent office and thus have not shown up in the patent database. Consistent with this conjecture, the number of patents in 2008,2009 and 2010 is $53 \%, 90 \%$, and $99 \%$ less than in 2007.
} 
Table 1

Summary statistics.

This table reports the summary statistics for a sample of U.S. firms from 1996 to 2007. Patents are the number of adjusted patents granted to the firm. Citations are the total number of adjusted citations received on the firm's patents filed (and eventually granted); Pat cite are the total number of patents weighted by the number of citations received as in Trajtenberg (1990); R\&D is research and development expenditure in millions of dollars; Outdir is the fraction of outside directors on a board; Leverage is book leverage, measured as long-term debt over total assets; ROA, Tangibility and Capital Expenditure are earnings before interest and tax (EBIT), net property, plant and equipment, and capital expenditure, respectively, divided by total assets; Board Size is the number of directors; CEO Stock Ownership is the percentage of stocks owned by CEOs; Institutional Ownership is the percentage of stocks owned by institutional investors; Total Assets are book assets measured in millions of dollars.

\begin{tabular}{|c|c|c|c|c|c|c|}
\hline \multicolumn{7}{|l|}{ Summary statistics } \\
\hline Variables & Mean & Median & Std. dev & Min & $\operatorname{Max}$ & No. of obs \\
\hline Patents & 0.087 & 0.018 & 0.184 & 0 & 1.876 & 6275 \\
\hline Citations & 0.098 & 0.019 & 0.203 & 0 & 1.867 & 6275 \\
\hline Pat_cite & 0.159 & 0.039 & 0.296 & 0 & 2.445 & 6275 \\
\hline $\mathrm{R} \& \overline{\mathrm{D}}$ & 237 & 38 & 737 & 0 & 12,183 & 6275 \\
\hline Outdir $(\%)$ & 0.695 & 0.714 & 0.165 & 0 & 1 & 6275 \\
\hline Leverage & 0.199 & 0.166 & 0.207 & 0 & 1.268 & 6204 \\
\hline $\mathrm{ROA}$ & 0.159 & 0.158 & 0.139 & -1.027 & 0.552 & 6213 \\
\hline Tangibility & 0.282 & 0.232 & 0.205 & 0.004 & 2.894 & 6215 \\
\hline Capital Expenditure (\%) & 0.063 & 0.047 & 0.059 & 0 & 0.487 & 6159 \\
\hline Total Assets & 7880 & 1488 & 23,997 & 80 & 276,543 & 6275 \\
\hline Board Size & 9.161 & 9 & 2.53 & 5 & 16 & 6275 \\
\hline CEO Stock Ownership (\%) & 0.03 & 0.015 & 0.048 & 0.001 & 0.292 & 5631 \\
\hline Institutional Ownership (\%) & 0.662 & 0.688 & 0.2 & 0.001 & 1 & 5597 \\
\hline
\end{tabular}

\subsection{Empirical results}

\subsubsection{Overall results on innovation}

Based on the discussion in the introduction, we use the following model to investigate the effect of board independence on innovation:

$$
\ln \left(1+\text { Innovaton }_{i t+1}\right)=\alpha+\beta_{t}+\theta_{1} \text { Outdir }_{i t}+\theta_{2} x_{i t}+\varepsilon_{i t}
$$

where Imovation $_{i t}+1$ is one of our three innovation measures for firm $i$ in year $t+1$. Outdir $r_{i t}$ is the fraction of outside directors for firm $i$ in year $t . \alpha$ is a constant while $\beta_{t}$ is year dummy which controls for overall trend in patenting activities. $x_{i t}$ is a set of firm - level controls as discussed earlier, and $\varepsilon_{i t}$ is the stochastic error term. Our coefficient of interest is $\theta_{1}$. While our main results are based on pooled OLS estimation, for robustness we also estimate this model by adding firm-fixed effect to controls for unobservable factors that are unique to specific firms. We cluster standard errors at the firm level to account for time series correlations in standard errors (Petersen, 2009).

Table 2 reports the regression results of model (2). Column (1), (2) and (3) are estimates from pooled OLS while (4), (5) and (6) are from firm-fixed effects. The fraction of outside directors loads positively and is statistically significant at the $5 \%$ level regardless of how innovation is measured and how the model is estimated. Taking column (2) as an example where innovation is measured as the number of adjusted citations, the coefficient estimate on board independence (outdir) is 0.097 . This means that outside directors have a positive effect on innovation. Results on the control variables from the OLS in general are consistent with existing literature. For example, the sign of the R\&D spending is positive and it is significant at 1\%, indicating large spending on research \& development appears to have a positive effect on innovation. ${ }^{7}$ Leverage is negatively associated with future patents possibly because firms with high leverage will have incentive to avoid innovative projects to reduce its exposure to risk. Institutional ownership is negatively associated with innovation, consistent with Becker-Blease (2011) but contradictory to Aghion et al. (2013). Lastly, larger firms are associated with more innovation. With an R-squared value close to 0.5, the independent variables in the pooled OLS seem to have a reasonably good explanatory power in explaining variation in innovation. In contrast, control variables from fixed effects, although have expected sign, mostly lose their statistical significance. The loss of statistical significance is likely due to the lack of meaningful time series variation for these variables. For this reason, in subsequent sections, we only present our results based on pooled OLS although our main inference remains unchanged when we add firm-fixed effects.

\footnotetext{
${ }^{7}$ Our results are qualitatively unchanged when we use R\&D capital (cumulative R\&D) instead of annual R\&D expenditure as our control. Following the literature, R\&D capital is calculated as:

$$
\mathrm{R} \& \mathrm{D} \text { Capital }_{i t}=\mathrm{R} \& \mathrm{D}_{i t}+0.8 * \mathrm{R} \& \mathrm{D}_{i t-1}+0.6 * \mathrm{R} \& \mathrm{D}_{i t-2}+0.4 * \mathrm{R} \& \mathrm{D}_{i t-3}+0.2 * \mathrm{R} \& \mathrm{D}_{i t-4}
$$
}

The results are in Appendix B. 
Table 2

Board independence and innovation: baseline results.

This table reports the pooled OLS (column (1), (2), and (3)) and firm-fixed effects (FE) (column (4), (5), and (6)) regression of innovation on board independence. The sample period is 1996 to 2007. Innovation is measured by the number of patents that are granted to the firm (Patents), the total number of citations received on the firm's patents (Citations), and the total number of patents weighted by the number of citations received (Pat_cite); all these measures have been adjusted for time effects and patent class effects (see Section 3.1 for more details); board independence is measured by the fraction of outside directors (Outdir). R\&D is Research \& Development expenditure; Leverage is book leverage, measured as long-term debt over total assets; ROA, asset tangibility and capital expenditure are earnings before interest and tax (EBIT), net property, plant and equipment, and capital expenditure, respectively, divided by total assets. Board Size is the number of directors; CEO Stock Ownership is the percentage of stocks owned by CEOs; Institutional Ownership is the percentage of stocks owned by institutional investors. Robust standard eirors that are clustered at the firm level are in parenthesis.

\begin{tabular}{|c|c|c|c|c|c|c|}
\hline \multirow[t]{3}{*}{ Variables } & \multicolumn{3}{|l|}{ Pooled OLS } & \multicolumn{3}{|l|}{ Firm-fixed effects } \\
\hline & (1) & (2) & (3) & (4) & (5) & (6) \\
\hline & $\ln \left(1+\right.$ Patents $\left._{t+1}\right)$ & $\ln \left(1+\right.$ Citations $\left._{t+1}\right)$ & $\ln (1+$ Pat_cite +1$)$ & $\ln \left(1+\right.$ Patents $\left._{t}+1\right)$ & $\ln \left(1+\right.$ Citations $\left._{t+1}\right)$ & $\ln \left(1+\right.$ Pat_cite $\left.t_{t+1}\right)$ \\
\hline \multirow[t]{2}{*}{ Outdir (\%) } & $0.090^{*+*}$ & $0.094^{* *}$ & $0.138^{* * *}$ & $0.037^{* *}$ & $0.050^{* *}$ & $0.073^{* *}$ \\
\hline & $(0.037)$ & $(0.038)$ & $(0.053)$ & $(0.018)$ & $(0.021)$ & $(0.030)$ \\
\hline \multirow[t]{2}{*}{$\ln (1+\mathrm{R} \& D)$} & $0.027^{* * *}$ & $0.030^{* * * *}$ & $0.046^{* * *}$ & -0.002 & -0.003 & -0.004 \\
\hline & $(0.004)$ & $(0.004)$ & $(0.006)$ & $(0.006)$ & $(0.006)$ & $(0.010)$ \\
\hline \multirow[t]{2}{*}{ Leverage } & $-0.076^{* * * *}$ & $-0.089^{* * * *}$ & $-0.132^{* * * *}$ & -0.014 & -0.009 & -0.020 \\
\hline & $(0.019)$ & $(0.021)$ & $(0.030)$ & $(0.009)$ & $(0.011)$ & $(0.016)$ \\
\hline \multirow[t]{2}{*}{ ROA } & $-0.061^{*}$ & -0.036 & -0.066 & -0.020 & -0.028 & -0.037 \\
\hline & $(0.036)$ & $(0.040)$ & $(0.056)$ & $(0.020)$ & $(0.022)$ & $(0.031)$ \\
\hline \multirow[t]{2}{*}{ Tangibility } & 0.043 & 0.028 & 0.060 & $0.044^{* k x}$ & 0.041 & $0.068^{*}$ \\
\hline & $(0.041)$ & $(0.049)$ & $(0.070)$ & $(0.020)$ & $(0.027)$ & $(0.037)$ \\
\hline \multirow[t]{2}{*}{ Capital Expenditure } & $0.156^{*}$ & $0.201^{* * * k}$ & $0.264^{* * *}$ & -0.022 & 0.013 & -0.007 \\
\hline & $(0.085)$ & $(0.092)$ & $(0.134)$ & $(0.036)$ & $(0.047)$ & $(0.068)$ \\
\hline \multirow[t]{2}{*}{ Board Size } & -0.001 & 0.000 & 0.000 & 0.001 & 0.002 & 0.003 \\
\hline & $(0.002)$ & $(0.003)$ & $(0.004)$ & $(0.002)$ & $(0.002)$ & $(0.003)$ \\
\hline \multirow[t]{2}{*}{ CEO Ownership } & 0.051 & 0.106 & 0.144 & -0.133 & -0.006 & -0.062 \\
\hline & $(0.081)$ & $(0.103)$ & $(0.138)$ & $(0.133)$ & $(0.135)$ & $(0.190)$ \\
\hline \multirow{2}{*}{$\begin{array}{l}\text { Institutional } \\
\text { Ownership }\end{array}$} & $-0.111^{* * * *}$ & $-0.107^{* * * * * *}$ & $-0.154^{* * *}$ & 0.016 & $0.033^{* *^{*}}$ & $0.038^{*}$ \\
\hline & $(0.038)$ & $(0.038)$ & $(0.053)$ & $(0.013)$ & $(0.014)$ & $(0.021)$ \\
\hline \multirow[t]{2}{*}{$\ln ($ Assets) } & $0.061^{* * * *}$ & $0.063^{*+*}$ & $0.097^{* * * *}$ & $0.016^{*+* *}$ & $0.016^{* * 4}$ & $0.026^{* * * *}$ \\
\hline & $(0.009)$ & $(0.010)$ & $(0.013)$ & $(0.006)$ & $(0.007)$ & $(0.010)$ \\
\hline \multirow[t]{2}{*}{ Constant } & $-0.359^{* * *}$ & $-0.240^{* *}$ & $-0.447^{*+*}$ & -0.060 & $-0.094^{*}$ & $-0.126^{*}$ \\
\hline & $(0.080)$ & $(0.094)$ & $(0.123)$ & $(0.045)$ & $(0.053)$ & $(0.075)$ \\
\hline Industry FE & Yes & Yes & Yes & $\mathrm{N} / \mathrm{A}$ & $\mathrm{N} / \mathrm{A}$ & $\mathrm{N} / \mathrm{A}$ \\
\hline Year FE & Yes & Yes & Yes & Yes & Yes & Yes \\
\hline Observations & 3683 & 3683 & 3683 & 3683 & 3683 & 3683 \\
\hline R-squared & 0.482 & 0.471 & 0.510 & 0.017 & 0.017 & 0.018 \\
\hline
\end{tabular}

* Statistical significance at the $10 \%$ level.

* Statistical significance at the $5 \%$ levels.

*** Statistical significance at the $1 \%$ level.

\subsubsection{Subsample analysis}

Managerial conservatism may vary from firm to firm because factors like firm size, industry, market competition, and financial leverage alter managers' risk preference. We argue that small firms, high-tech firms, firms in competitive industries, and firms with less financial leverage are less prone to excessive managerial conservatism. Large firms usually enjoy a large market share and a large and stable cash flow, which allow the managers to survive relatively easily without having to take a lot of risks. They thus have less incentive to innovate. To survive, firms in high-tech industries have to continuously experiment with creative ideas and search for ways to turn these ideas into viable commercial products. Compared to traditional firms, managers of hightech firms have more incentive to innovate. Market competition mitigates agency conflicts and serves as a corporate governance mechanism (e.g., Stigler, 1958; Shleifer and Vishny, 1997; Giroud and Mueller, 2010). In a competitive environment, managers have to take up risky endeavors like innovation because their careers and wealth hinge on the survival of the firms. In addition, the use of debt increases a firm's risk, which in turn could exacerbate managerial conservatism (Gormley and Matsa, 2016). To the extent that an independent board alleviates excessive managerial conservatism, we postulate that the effect of board independence on corporate innovation should be more pronounced in large firms, traditional firms, firms in less competitive industries, and firms with greater financial leverage.

We test these hypotheses by estimating model (2) in subsamples based on firm size, high-tech industry, product market competition, and debt-to-asset ratio. Firms whose average assets over our sample period are above the median average size of all firms are designated as large firms, and the rest small firms. Technical firms are firms in the industries as defined by Loughran and Ritter (2004), which includes computer hardware, communications equipment, electronics, navigation equipment, measuring and controlling devices, medical instruments, telephone equipment, communications services, and software. Following Giroud and Mueller (2010), we use the Herfindahl-Hirschman index (HHI) to measure industry competitiveness. We classify industries using four-digit standard industry classification (SIC) code; industries with below-median HHI are designated as competitive industries. Lastly, firms with above-median debt-to-asset ratios are designated as high-leverage firms, and the rest low-leverage ones. Results from the subsample analysis are in Table 3. 
Table 3

Board independence and innovation: subsample analysis based on different groups.

This table reports the pooled OLS regression of innovation on board independence for a sample of U.S. firms from 1996 to 2007 based on different groups: Large firms are firms with average total assets above the median average assets for all firms; tech-firms are firms in technical industries as defined in Loughran and Ritter (2004), Appendix D; industry competitiveness is measured using the Herfindahl-Hirschman index ( $\mathrm{HHI}$ ). Industries with $\mathrm{HHI}$ below the median HHI for all industries in a year are classified as competitive industries. Firms with above-median debt-to-asset ratio are high leveraged firms, and those below are low-leverage ones. Innovation is measured by the number of patents that are granted to the firm (Patents), the total number of citations received on the firm's patents (Citations), and the total number of patents weighted by the number of citations received ( $P_{a t}$ cite); all these measures have been adjusted for time effects and patent class effects (see Section 3.1 for more details); board independence is measured by the fraction of outside directors (Outdir). The control variables (Controls) include ln( $1+$ R\&D), Leverage, ROA, asset tangibility, capital expenditure, Board Size, CEO Stock Ownership, Institutional Ownership. Definitions of these variables are provided in Table 2. All controls include industry and year fixed effects. Robust standard errors, clustered at the firm level are in parenthesis.

\begin{tabular}{|c|c|c|c|c|c|c|}
\hline \multicolumn{7}{|c|}{ Panel A: Large firms vs. small firms } \\
\hline \multirow[t]{3}{*}{ Variables } & \multicolumn{3}{|l|}{ Large firms } & \multicolumn{3}{|l|}{ Small firms } \\
\hline & $(1)$ & $(2)$ & (3) & $(1)$ & $(2)$ & (3) \\
\hline & $\ln \left(1+\right.$ Patents $\left._{t+1}\right)$ & $\ln \left(1+\right.$ Citations $\left._{t+1}\right)$ & $\ln \left(1+\right.$ Pat_cite $\left._{t+1}\right)$ & $\ln \left(1+\right.$ Patents $\left._{t}+1\right)$ & $\ln \left(1+\right.$ Citations $\left._{t}+1\right)$ & $\ln \left(1+\right.$ Pat_cite $\left._{t+1}\right)$ \\
\hline Outdir (\%) & $\begin{array}{l}0.110^{* * *} \\
(0.054)\end{array}$ & $\begin{array}{l}0.104^{*} \\
(0.056)\end{array}$ & $\begin{array}{l}0.157^{* *} \\
(0.079)\end{array}$ & $\begin{array}{l}0.003 \\
(0.008)\end{array}$ & $\begin{array}{l}0.020 \\
(0.016)\end{array}$ & $\begin{array}{l}0.021 \\
(0.021)\end{array}$ \\
\hline Controls & Yes & Yes & Yes & Yes & Yes & Yes \\
\hline Observations & 2308 & 2308 & 2308 & 1375 & 1375 & 1375 \\
\hline R-squared & 0.496 & 0.481 & 0.512 & 0.211 & 0.186 & 0.218 \\
\hline
\end{tabular}

Panel B: Non-tech vs. tech firms

\begin{tabular}{|c|c|c|c|c|c|c|}
\hline \multirow[t]{3}{*}{ Variables } & \multicolumn{3}{|l|}{ Non-tech Firms } & \multicolumn{3}{|l|}{ Tech firms } \\
\hline & (1) & (2) & (3) & (1) & (2) & (3) \\
\hline & $\ln \left(1+\right.$ Patents $\left._{t}+1\right)$ & $\ln \left(1+\right.$ Citation $\left._{t}+1\right)$ & $\ln \left(1+\right.$ Pat_cite $\left._{r}+1\right)$ & $\ln \left(1+\right.$ Patent $\left._{t+1}\right)$ & $\ln \left(1+\right.$ Citations $\left._{t}+1\right)$ & $\ln \left(1+\right.$ Pat_cite $\left._{t+1}\right)$ \\
\hline Outdir (\%) & $\begin{array}{l}0.075^{* *} \\
(0.031)\end{array}$ & $\begin{array}{l}0.081^{* *} \\
(0.035)\end{array}$ & $\begin{array}{l}0.128^{* *} \\
(0.053)\end{array}$ & $\begin{array}{l}0.124 \\
(0.082)\end{array}$ & $\begin{array}{l}0.124 \\
(0.082)\end{array}$ & $\begin{array}{l}0.168 \\
(0.109)\end{array}$ \\
\hline Controls & Yes & Yes & Yes & Yes & Yes & Yes \\
\hline Observations & 2513 & 2513 & 2513 & 1170 & 1170 & 1170 \\
\hline R-squared & 0.530 & 0.507 & 0.537 & 0.481 & 0.465 & 0.515 \\
\hline
\end{tabular}

Panel C: Competitive industry vs. non-competitive industry

\begin{tabular}{|c|c|c|c|c|c|c|}
\hline \multirow[t]{3}{*}{ Variables } & \multicolumn{3}{|l|}{ Non-competitive } & \multicolumn{3}{|l|}{ Competitive } \\
\hline & (1) & (2) & (3) & (1) & (2) & (3) \\
\hline & $\ln \left(1+\right.$ Patents $\left._{t}+1\right)$ & $\ln \left(1+\right.$ Citations $\left._{t+1}\right)$ & $\ln \left(1+P_{a t} c i t e_{t}+1\right)$ & $\ln \left(1+\right.$ Patents $\left._{t+1}\right)$ & $\ln \left(1+\right.$ Citations $\left._{t+1}\right)$ & $\ln \left(1+\right.$ Pat_cite $\left.e_{t+1}\right)$ \\
\hline Outdir $(\%)$ & $\begin{array}{l}0.201^{* * * *} \\
(0.077)\end{array}$ & $\begin{array}{l}0.206^{* * *} \\
(0.081)\end{array}$ & $\begin{array}{l}0.311^{* * * *} \\
(0.110)\end{array}$ & $\begin{array}{l}0.059^{*} \\
(0.033)\end{array}$ & $\begin{array}{l}0.063^{*} \\
(0.035)\end{array}$ & $\begin{array}{l}0.090^{*} \\
(0.052)\end{array}$ \\
\hline Controls & Yes & Yes & Yes & Yes & Yes & Yes \\
\hline Observations & 796 & 796 & 796 & 2723 & 2723 & 2723 \\
\hline R-squared & 0.532 & 0.523 & 0.576 & 0.494 & 0.479 & 0.509 \\
\hline
\end{tabular}

Panel D: High leverage vs. Low leverage

\begin{tabular}{|c|c|c|c|c|c|c|}
\hline \multirow[t]{3}{*}{ Variables } & \multicolumn{3}{|l|}{ High leverage } & \multicolumn{3}{|l|}{ Low leverage } \\
\hline & (1) & (2) & (3) & (1) & (2) & (3) \\
\hline & $\ln \left(1+\right.$ Patents $\left._{t+1}\right)$ & $\ln \left(1+\right.$ Citations $\left._{t+1}\right)$ & $\ln \left(1+\right.$ Pat_cite $\left._{t+1}\right)$ & $\ln \left(1+\right.$ Patents $\left._{t+1}\right)$ & $\ln \left(1+\right.$ Citations $\left._{t+1}\right)$ & $\ln \left(1+\right.$ Pat_cite $\left.{ }_{t+1}\right)$ \\
\hline Outdir (\%) & $\begin{array}{l}0.153^{* * *} \\
(0.064)\end{array}$ & $\begin{array}{l}0.144^{* * *} \\
(0.067)\end{array}$ & $\begin{array}{l}0.218^{* * *} \\
(0.092)\end{array}$ & $\begin{array}{l}0.045 \\
(0.033)\end{array}$ & $\begin{array}{l}0.053 \\
(0.036)\end{array}$ & $\begin{array}{l}0.075 \\
(0.054)\end{array}$ \\
\hline Controls & Yes & Yes & Yes & Yes & Yes & Yes \\
\hline Observations & 1473 & 1473 & 1473 & 2210 & 2210 & 2210 \\
\hline R-squared & 0.610 & 0.577 & 0.612 & 0.449 & 0.445 & 0.484 \\
\hline
\end{tabular}

* Statistical significance at the $10 \%$ level.

* Statistical significance at the 5\% levels.

** Statistical significance at the $1 \%$ level.

In Panel A, board independence obtains a statistically significant, positive coefficient in the subsample of large firms, regardless of the measure of innovation; its coefficients in the subsample of small firms are much smaller in magnitude and statistically insignificant. Thus board independence encourages innovation only for large firms. This finding is consistent with Coles et al.'s (2008) observation that in large firms, more outside directors increase firm value. Similarly, our board independence measure loads only in subsamples of firms from non-technical industries (Panel B), of firms from industries with low product market competition (Panel C), and of firms with high financial leverage (Panel D), but not in subsamples of high-tech firms, firms from competitive industries or low-leverage firms. These results are consistent with our expectations. 


\subsubsection{Board independence and RED expenditure}

Our premise is that a greater board representation by outside directors makes managers engage in riskier investments. Previously, we have shown a positive relation between board independence and innovation as proxied by patents and citations. However, patents and citations can only be viewed as a measure of success of risk-taking activities, not just the extent of risk-taking. ${ }^{8}$ To see whether board independence indeed boost managerial risk preference, we use R\&D expenditure as our risk-taking measure. $R \& D$ expenditure is a natural candidate because investments in $R \& D$ is one of the major managerial decisions, and arguably one of the most important ingredients in generating innovation, and it is typically viewed as risky compared to property, plant, and equipment investments. If our managerial risk-aversion argument is correct, we should expect a positive relation between board independence and innovation.

We re-estimate model (2) using R\&D expenditure as the dependent variable. We start with a parsimonious specification and then add additional controls across the columns. In Column (1) of Table 4, Panel A, we regress R\&D expenditure on board independence controlling only for firm size, industry, and the year trend, we find the coefficient on board independence is positive and statistically significant at the $10 \%$ level. We add other firm characteristics such as leverage, profitability, etc. in column (2), and further include governance variables as additional controls in column (3). We find that our results are even stronger in term of both the magnitude and significance level. Next, we repeat our exercise of examining the relation in different groups of firms. The results are in Panel B of Table 4. Again, consistent with previous findings of differential impacts of board independence on innovation, we find that the positive relation on board independence and $R \& D$ expenditure is driven by firms mostly susceptible to managerial conservatism. Collectively, these results strengthen our argument that board independence helps to combat managerial conservatism.

\section{Endogeneity issues}

A statistically significant association between board independence and innovation may not be interpreted as a causal relationship in the presence of potential endogeneity of board composition (Hermalin and Weisbach, 1998; Adams et al., 2010). The typical endogeneity problem arises from omitted variables and reverses causality. In our case, firms with different board structure likely differ in other unobservable ways; in addition, a firm's choice of governance structure is in a large part a response to observable and unobservable or firm-specific characteristics (Bhagat and Black, 2001). The fixed effect model in Table 2 can reduce omitted variable bias to some extent, but does not solve the problem of reverse causality. In the following sections, we attempt to establish causality by employing a difference-in-difference approach that exploits an exogenous change in board composition.

\subsection{Institutional background and exogenous change in board independence}

A series of corporate scandals at the beginning of this century (e.g., Enron) led to the passage of Sarbanes-Oxley Act (SOX) in 2002 that embarked on massive corporate governance reforms. As a direct response to SOX, two major national stock exchanges - the NYSE and the NASDAQ revised their listing requirements by mandating a majority of independent directors for all firms listed on the exchanges. ${ }^{9}$ The initial proposal for revision was announced in 2002 and was approved by SEC on November 4, 2003. Listed companies must be in compliance with the new listing standards by the earlier day of their first annual meeting of shareholders held after January 15,2004 and October 31, 2004. An exception is that companies with staggered boards are given an additional year for compliance.

The new listing requirements of the NYSE and the NASDAQ are likely to create an exogenous shock to board structure because these requirements are mandatory in the sense that firms that did not comply were forced to change the composition of their boards by increasing the representation of outside directors. ${ }^{10}$ These firms serve as our treated firms. As pointed out by Chhaochharia and Grinstein (2007), "the new governance rules offer a unique laboratory to test the effect of governance structure on firm value since the rules can be considered an outside intervention to the governance structure of firms." Compared to many government policies that impact all firms, this new listing requirement confers an additional advantage: a proportion of listed firms had already a majority of independent directors prior to SOX and hence, these firms constitute a convenient control group.

Our identification strategy is a difference-in-difference test, which essentially compares changes in innovation around the time of the new listing requirements between firms that experienced the exogenous shock in board composition and the control firms. One critical condition for this methodology is that the new listing requirements indeed created an exogenous shock to board independence. To visually see if this is the case, in Fig. 1 we plot a time series graph of the average proportion of outside directors from 1996 to 2007, separately for the non-compliant (i.e., firms that did not have a majority of outside directors prior to the exchange mandates) and compliant firms. For compliant firms, although the proportion of outside directors has been steadily increasing, this trend is relatively smooth: over this decade, the proportion of outside directors has increased from about $64 \%$ in 1996 to nearly $80 \%$ in 2005 . In comparison, the pattern for the non-compliant firms is much different: prior to the new listing

\footnotetext{
${ }^{8}$ We thank an anonymous referee for bringing up this point.

${ }^{9}$ More details regarding the evolution of SOX and subsequent actions taken by the NYSE and the NASDAQ in response to SOX have been given in many previous research such as Coates (2007), and Chhaoch hatia and Grinstein (2007, 2009).

${ }^{10}$ For example, in Activision's 2003 proxy statement, it states that "The Company's Board of Directors is composed of four independent directors and three management directors, and independent directors have comprised a majority of the Board for over ten years. The Company complies with existing NASDAQ rules defining independent directors, and believes that it will continue to be in compliance with the new and proposed rules of the NASDAQ regarding Board composition." Abercrombie \& Fitch Co.'s 2003 proxy statement states that "The Board of Directors is in the process of reviewing the rules proposed by NYSE relating to the Audit, Compensation and Nominating and Board Govemance Committees and intends to take appropriate action to comply with the NYSE rules and the SEC's rules and regulations implementing the Sarbanes-Oxley Act as those rules and regulations are finalized and implemented."
} 
Table 4

Board independence and R\&D expenditure.

This table reports the pooled OLS regression of R\&D expenditure on board independence. The sample period is 1996 to 2007 . The dependent variable is $\ln (1+\mathrm{R} \& \mathrm{D})$. Panel A examines the overall relation between R\&D and board independence while Panel B examines the relation based on different groups. Large firms are firms with average total assets above the median average assets for all firms; tech-firms are firms in technical industries as defined in Loughran and Ritter (2004), Appendix D industry competitiveness is measured using the Herfindahl-Hirschman index ( $\mathrm{HHI}$ ). Industries with $\mathrm{HHI}$ below the median $\mathrm{HHI}$ for all industries in a year are classified as competitive industries. Firms with above-median debt-to-asset ratio are high leveraged firms, and those below are low-leverage ones. Board independence is measured by the fraction of outside directors (Outdir); Leverage is book leverage, measured as long-term debt over total assets; ROA, asset tangibility and capital expenditure are earnings before interest and tax (EBIT), net property, plant and equipment, and capital expenditure, respectively, divided by total assets. Board Size is the number of directors; CEO Stock Ownership is the percentage of stocks owned by CEOs; Institutional Ownership is the percentage of stocks owned by institutional investors. Robust standard errors that are clustered at the firm level are in parenthesis.

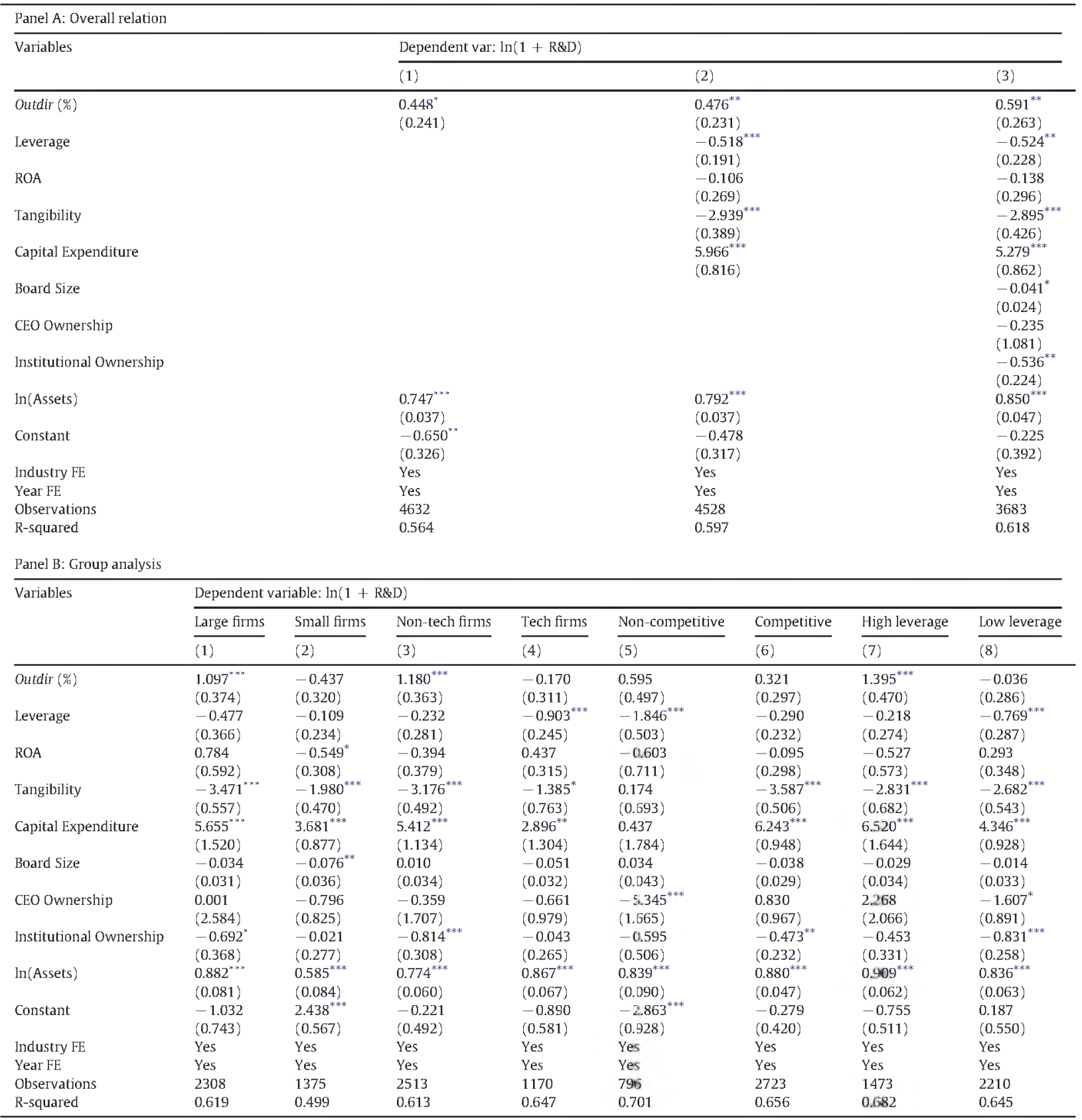

* Statistical significance at the $10 \%$ level.

** Statistical significance at the $5 \%$ levels.

*** Statistical significance at the $1 \%$ level. 


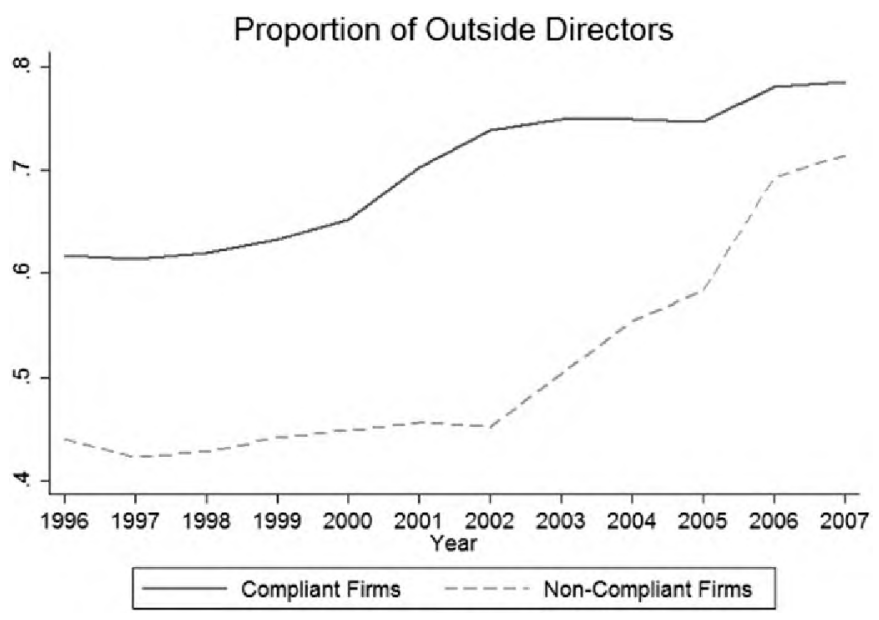

Fig. 1. Time series plot of the average fraction of outside directors on board. Compliant firms (non-compliant firms) are those which have (do not have) a majority of outside directors in 2002.

requirements, the ratio of outside directors remains within a narrow range between 40 and $45 \%$; starting in 2002, it picked up at a dramatic pace, rising from a little over $40 \%$ in 2002 to over $50 \%$ in 2003 and then to nearly $70 \%$ in 2006 . The difference in the board composition pattern demonstrates that non-compliant firms indeed made efforts to comply with the new listing requirement by adding outside directors, while compliant firms were largely unaffected by the requirement. Hence a difference-in-difference strategy would be valid when the compliant firms serve as the control group.

\subsection{Difference-in-difference (DiD) tests}

Based on the discussion from the previous section, we specify our difference-in-difference model as follows:

$$
\ln \left(1+\text { Innovaton }_{i t+1}\right)=\alpha_{i}+\beta_{t}+\theta_{1} \text { Treated }_{i t} * \text { After }_{t}+\theta_{2} x_{i t}+\varepsilon_{i t}
$$

where Treated $_{i t}$ is a dummy which equals one if firms do not have a majority of outside directors in year 2002 , After $t_{t}$ is an indicator for periods after 2002, $\alpha_{i}$ is firm-fixed effect and the rest are defined as in model (2). $\theta_{1}$ is our coefficient of interest which essentially captures the change in innovation when firms change their board structure from boards with a minority of outside directors to a majority of outside directors. We expect the coefficient $\theta_{1}$ to be positive and statistically significant.

Intuitively, how this model provides an estimate of the causal effect of board independence on innovation can be understood through an example. Let's suppose there are two firms, $T$, the treated firm and C, the control firm. Firm $T$ did not have a majority of independent directors before 2003 and thus is forced to increase board independence as mandated by the new listing requirement. In contrast, firm C need not change its board structure because it already had a majority of independent directors before 2003.To gauge the effect of the exogenous increase in board independence on innovation, we could simply compare innovation for firm T before and after 2003, and use this difference as the estimate of the effect. However, one potential drawback is that, because the treated firms are given approximately two years to comply with the requirement, significant changes such as industry shocks may affect firms' innovating activities during this period but has nothing to do with firms' board structure. Without appropriately controlling for these confounding factors, it will be difficult to interpret the previous result as the effect of board independence. One way to deal with this issue is to use firm $C$ as the control, and if we assume that industry shocks would impact the control firm in terms of innovation in the same way as they would impact the treated firm, then we can use the difference in innovation for firm $\mathrm{C}$ as the benchmark in the absence of a significant change in board independence. The difference between the estimate for treated firms and the benchmark provides a causal effect of board independence on innovation.

Eq. (3) essentially combines the two simple comparisons into one regression. It compares the innovative output before and after the mandatory board structure change for non-compliant firms, with compliant firms serving as a control group, thus effectively controlling for both unobserved time-invariant firm-specific heterogeneity (e.g., management quality) and unobserved time effects. It is also worth noting that introducing a control group in this study is especially important because it takes an average of two years for a patent application to be approved, which leads to a mechanic decrease in the number of patents over time even in the absence of any change in board structure. Again, we cluster standard errors at the firm level.

Table 5 reports the DiD estimates from model (3) using a sample of firms that are listed on the NYSE and the NASDAQ over the period 2001-2007. 2001 is the year prior to the sweeping governance reform as introduced by the passage of SOX, thus can serve as the pre-treatment innovation condition for the non-compliant firms. ${ }^{11}$ We find that a positive and statistically significant coefficient obtains on the interaction terms for citations and citation-weighted patents. The estimate in column (3) implies that,

\footnotetext{
$\overline{11}$ Our results are robust to different sample periods such as $2000-2007$.
} 
Table 5

Difference-in-difference estimates of the effect of board independence on corporate innovation.

This table reports the difference-in-difference estimate of the effect of board independence on innovation. The sample period is 2001-2007. Innovation is measured by the number of patents that are granted to the firm (Patents), the total number of citations received on the firm's patents (Citations), and the total number of patents weighted by the number of citations received (Pat_cite); all these measures have been adjusted for time effects and patent class effects (see Section 3.1 for more details); Treated is a dummy variable which equals one if a firm does not have a majority of independent directors in 2002, zero otherwise; After is an indicator for years after 2002; R\&D is Research \& Development expenditure; Leverage is book leverage, measured as long-term debt over total assets; ROA, asset tangibility and capital expenditure are earnings before interest and tax (EBIT), net property, plant and equipment, and capital expenditure, respectively, divided by total assets. Board Size is the number of directors; CEO Stock Ownership is the percentage of stocks owned by CEOs; Institutional Ownership is the percentage of stocks owned by institutional investors. Robust standard etrors, clustered at the firm level are in parenthesis.

\begin{tabular}{|c|c|c|c|}
\hline \multirow[t]{2}{*}{ Variables } & (1) & (2) & (3) \\
\hline & $\ln \left(1+\right.$ Patents $\left._{t+1}\right)$ & $\ln \left(1+\right.$ Citations $\left._{t+1}\right)$ & $\ln (1+$ Pat_cite +1$)$ \\
\hline \multirow[t]{2}{*}{ Treated * After } & 0.007 & $0.020^{* * *}$ & $0.025^{* * *}$ \\
\hline & $(0.005)$ & $(0.008)$ & $(0.010)$ \\
\hline \multirow[t]{2}{*}{$\ln (1+R \& D)$} & 0.002 & 0.001 & 0.002 \\
\hline & $(0.002)$ & $(0.003)$ & $(0.004)$ \\
\hline \multirow[t]{2}{*}{ Leverage } & -0.012 & $-0.043^{* * * *}$ & $-0.048^{* * *}$ \\
\hline & $(0.012)$ & $(0.014)$ & $(0.020)$ \\
\hline \multirow[t]{2}{*}{ ROA } & 0.000 & 0.006 & 0.018 \\
\hline & $(0.023)$ & $(0.032)$ & $(0.042)$ \\
\hline \multirow[t]{2}{*}{ Tangibility } & $0.094^{* * * * *}$ & $0.126^{* * * * *}$ & $0.184^{* * * *}$ \\
\hline & $(0.032)$ & $(0.044)$ & $(0.059)$ \\
\hline \multirow[t]{2}{*}{ Capital Expenditure } & -0.062 & -0.008 & -0.072 \\
\hline & $(0.054)$ & $(0.071)$ & $(0.099)$ \\
\hline \multirow[t]{2}{*}{ Board Size } & 0.002 & 0.003 & 0.004 \\
\hline & $(0.002)$ & $(0.002)$ & $(0.003)$ \\
\hline \multirow[t]{2}{*}{ CEO Ownership } & -0.069 & 0.048 & -0.005 \\
\hline & $(0.090)$ & $(0.061)$ & $(0.101)$ \\
\hline \multirow[t]{2}{*}{ Institutional Ownership } & 0.007 & $0.044^{* *}$ & 0.045 \\
\hline & $(0.018)$ & $(0.021)$ & $(0.029)$ \\
\hline \multirow[t]{2}{*}{$\ln$ (Assets) } & 0.012 & $0.024^{* * * *}$ & $0.030^{*+4}$ \\
\hline & $(0.008)$ & $(0.009)$ & $(0.012)$ \\
\hline \multirow[t]{2}{*}{ Constant } & -0.032 & $-0.140^{* *}$ & -0.146 \\
\hline & $(0.060)$ & $(0.063)$ & $(0.093)$ \\
\hline Firm FE & Yes & Yes & Yes \\
\hline Year FE & Yes & Yes & Yes \\
\hline Observations & 1999 & 1999 & 1999 \\
\hline R-squared & 0.018 & 0.039 & 0.033 \\
\hline
\end{tabular}

* Statistical significance at the $10 \%$ level.

*** Statistical significance at the $5 \%$ levels.

*** Statistical significance at the $1 \%$ level.

relative to the compliant firms, a switch from a board with a minority of outside directors to a board with majority of outsiders is associated with a 2.5 percent increase in citation-weighted patents. This result is consistent with the previous findings. ${ }^{12}$ The control variables have expected signs, but for reasons discussed earlier, they lose their statistical significance.

\subsection{DiD estimation in matched sample}

To establish a causal link between board independence and innovation, the DiD specification in Eq. (3) assumes that firms that already had a majority of outside directors before the exchange mandate provide a good counterfactual to the treated firms. To check whether this assumption is satisfied, we compare the treated and control firms on various aspects such as firm size, $R \& D$, and leverage that might affect firms' treatment status. Table 6 , Panel A presents the summary statistics of these firm characteristics for treated and control firms separately. The statistics are computed based on averages for the years 2000 and 2001 , the two years immediately prior to the SOX being passed. We find that the treated firms differ from the control firms in several aspects: on average they have better operating performance, are much smaller, and spend less on R\&D than control firms, and their CEOs hold a larger percentage of stocks than the control firms. Although we use these variables in our DiD estimation to control for their observable differences, it may not completely address the endogeneity issue because firms in the treated group may simply fail to find their controls.

We address this issue by employing the propensity score matching (PSM), which essentially creates a new sample of firms wherein treated firms are matched to the control firms in various dimensions. When applying this strategy, we first estimate a logit model based on all sample firms in 2000 and 2001. The dependent variable is a dummy variable that equals one if the firm did not have a majority of independent directors in 2002 and zero otherwise. The independent variables include all the

\footnotetext{
12 While we exploit the exogenous change in board composition, this research does not intend to assess whether and to what extent the governance structure of the non-compliant firms represent an "out of equilibrium" condition prior to the new listing requirement. One possibility, as proposed by Coles et al. (2008), could be the transaction cost. Since it is not the focus of this research, we refer readers to that paper for more discussion.
} 
Table 6

Propensity score matching.

This table reports summary statistics (Panels A and B) and the results of a difference-in-differences model (Panel C), using a sample matched on propensity scores. We match the treated firms with the control firms using one-to-one nearest neighbor propensity score matching, with replacement. The propensity scores are estimated from a logit model that uses the averages over 2000-2001. Patents are the number of adjusted patents that are granted to the firm. Citations are the total number of adjusted citations received on the firm's patents filed (and eventually granted); Pat cite are the total number of patents weighted by the number of citations received as in Trajtenberg (1990); Treated is a dummy variable which equals one if a firm does not have a majority of independent directors in 2002, zero otherwise; After is an indicator for years after 2002; R\&D is research and development expenditure in millions of dollars; Leverage is book leverage, measured as long-term debt over total assets; ROA, tangibility and capital expenditure are earnings before interest and tax (EBIT), net property, plant and equipment, and capital expenditure, respectively, divided by total assets; Board Size is the number of directors; CEO Stock Ownership is the percentage of stocks owned by CEOs; Institutional Ownership is the percentage of stocks owned by institutional investors; Total Assets are book assets measured in millions of dollars.

\begin{tabular}{|c|c|c|c|c|c|}
\hline \multicolumn{6}{|l|}{ Panel A: Before match } \\
\hline \multirow[t]{2}{*}{ Variable } & \multicolumn{2}{|l|}{ Treated firms } & \multicolumn{2}{|l|}{ Control firms } & \multirow[t]{2}{*}{ Difference } \\
\hline & Mean & $\overline{\mathrm{Obs}}$ & Mean & Obs & \\
\hline$R \& D$ & 79.75 & 79 & 193.09 & 677 & $-113.35^{\text {**** }}$ \\
\hline Leverage & 0.20 & 77 & 0.22 & 664 & -0.02 \\
\hline ROA & 0.17 & 77 & 0.11 & 664 & $0.06^{* * *}$ \\
\hline Tangibility & 0.30 & 78 & 0.27 & 663 & 0.03 \\
\hline Capital Expenditure (\%) & 0.08 & 76 & 0.08 & 645 & 0.00 \\
\hline Board Size & 8.37 & 79 & 8.84 & 677 & -0.46 \\
\hline CEO Stock Ownership (\%) & 0.06 & 77 & 0.03 & 578 & $0.03^{* * *}$ \\
\hline Institutional Ownership (\%) & 0.00 & 61 & 0.00 & 594 & 0.00 \\
\hline Total Assets & 3681 & 79 & 12,690 & 677 & $-9009^{* * *}$ \\
\hline \multicolumn{6}{|l|}{ Panel B: After match } \\
\hline \multirow[t]{2}{*}{ Variable } & \multicolumn{2}{|l|}{ Treated firms } & \multicolumn{2}{|l|}{ Control firms } & \multirow[t]{2}{*}{ Difference } \\
\hline & Mean & Obs & Mean & Obs & \\
\hline R\&D & 104.74 & 54 & 116.07 & 48 & -11.33 \\
\hline Leverage & 0.19 & 54 & 0.19 & 48 & 0.00 \\
\hline $\mathrm{ROA}$ & 0.17 & 54 & 0.16 & 48 & 0.01 \\
\hline Tangibility & 0.30 & 54 & 0.33 & 48 & -0.03 \\
\hline Capital Expenditure (\%) & 0.07 & 54 & 0.07 & 48 & 0.00 \\
\hline Board Size & 8.49 & 54 & 8.72 & 48 & -0.23 \\
\hline CEO Stock Ownership (\%) & 0.07 & 54 & 0.05 & 48 & 0.02 \\
\hline Institutional Ownership (\%) & 0.00 & 54 & 0.00 & 48 & 0.00 \\
\hline Total Assets & 2158 & 54 & 3118 & 48 & -960 \\
\hline \multicolumn{6}{|c|}{ Panel C: DiD estimates in matched sample } \\
\hline \multirow[t]{2}{*}{ Variables } & \multicolumn{2}{|l|}{ (1) } & \multicolumn{2}{|l|}{$(2)$} & (3) \\
\hline & \multicolumn{2}{|l|}{$\overline{\ln \left(1+\text { Patent }_{t}+1\right)}$} & \multicolumn{2}{|l|}{$\overline{\ln \left(1+\text { Citations }_{t}+1\right)}$} & $\ln \left(1+\right.$ Pat_cite $\left._{t+1}\right)$ \\
\hline Treated * After & \multicolumn{2}{|l|}{0.013} & $\begin{array}{l}0.022^{*} \\
(0.011)\end{array}$ & & $\begin{array}{l}0.032^{* * *} \\
(0.016)\end{array}$ \\
\hline $\ln (1+R \& D)$ & -0.014 & & 0.001 & & -0.014 \\
\hline & $(0.012)$ & & $(0.016)$ & & $(0.024)$ \\
\hline Leverage & -0.035 & & $-0.100^{* *}$ & & $-0.117^{* *}$ \\
\hline & $(0.034)$ & & $(0.042)$ & & $(0.056)$ \\
\hline ROA & 0.052 & & $0.158^{* *}$ & & $0.192^{* * *}$ \\
\hline & $(0.047)$ & & $(0.063)$ & & $(0.092)$ \\
\hline Tangibility & 0.104 & & 0.069 & & 0.147 \\
\hline & $(0.087)$ & & $(0.095)$ & & $(0.152)$ \\
\hline Capital Expenditure & $-0.263^{* *}$ & & -0.104 & & $-0.328^{*}$ \\
\hline & $(0.103)$ & & $(0.127)$ & & $(0.190)$ \\
\hline Board Size & -0.001 & & -0.005 & & -0.004 \\
\hline & $(0.002)$ & & $(0.004)$ & & $(0.005)$ \\
\hline CEO Ownership & -0.056 & & -0.011 & & -0.053 \\
\hline & $(0.085)$ & & $(0.086)$ & & $(0.141)$ \\
\hline Institutional Ownership & 0.024 & & $0.082^{*}$ & & 0.089 \\
\hline & $(0.025)$ & & $(0.049)$ & & $(0.061)$ \\
\hline $\ln$ (Assets) & 0.022 & & 0.038 & & $0.053^{*}$ \\
\hline & $(0.015)$ & & $(0.024)$ & & $(0.032)$ \\
\hline Constant & -0.071 & & -0.238 & & -0.256 \\
\hline & $(0.114)$ & & $(0.183)$ & & $(0.244)$ \\
\hline Firm FE & Yes & & Yes & & Yes \\
\hline Year FE & Yes & & Yes & & Yes \\
\hline Observations & 322 & & 322 & & 322 \\
\hline R-squared & 0.059 & & 0.098 & & 0.085 \\
\hline
\end{tabular}

* Statistical significance at the $10 \%$ level.

** Statistical significance at the $5 \%$ levels.

*** Statistical significance at the $1 \%$ level. 
Table 7

Board independence and choice of equity based compensation for CEOs.

This table reports the pooled OLS regression of CEO equity compensation on board independence during 1996-2007. Stock grants and option grants are the dependent variables, and refer to stock compensation and option compensation, respectively, as a percentage of total compensation for CEOs; Outdir (\%) is the fraction of outside directors; CEO/Chairman duality is equal to one if the CEO and Chairman of the board is the same person and zero otherwise; leverage is measured as long-term debt over total assets; market-to-book is the market value of total assets over book value of total assets; Cash Flow/Assets is operating cash flow over total assets. All independent variables are measured with one-year lag. All regressions include industry effects and year fixed effects. Standard errors, clustered at firm level, are in parenthesis.

\begin{tabular}{|c|c|c|c|c|}
\hline \multirow[t]{2}{*}{ Variables } & \multicolumn{2}{|c|}{ Stock grants } & \multicolumn{2}{|c|}{ Option grants } \\
\hline & $\overline{(1)}$ & (2) & $\overline{(3)}$ & (4) \\
\hline Outdir (\%) & 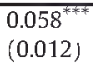 & 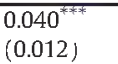 & 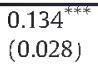 & $\begin{array}{l}0.122^{\text {F*3*1*}} \\
(0.027)\end{array}$ \\
\hline $\mathrm{CEO}$ /Chairman duality & & $\begin{array}{l}-0.001 \\
(0.004)\end{array}$ & & $\begin{array}{l}-0.018^{* *} \\
(0.008)\end{array}$ \\
\hline Leverage & & $\begin{array}{l}0.034^{* * * *} \\
(0.010)\end{array}$ & & $\begin{array}{l}-0.050^{* *} \\
(0.021)\end{array}$ \\
\hline Market-to-Book & & $\begin{array}{l}-0.003^{* * * *} \\
(0.001)\end{array}$ & & $\begin{array}{l}0.024^{* * * * *} \\
(0.002)\end{array}$ \\
\hline Cash Flow/Assets & & $\begin{array}{l}0.051^{* * *} \\
(0.024)\end{array}$ & & $\begin{array}{l}-0.102^{*} \\
(0.054)\end{array}$ \\
\hline $\ln$ (Assets) & & $\begin{array}{l}0.012^{* * * * *} \\
(0.002)\end{array}$ & & $\begin{array}{l}0.027^{* * * *} \\
(0.004)\end{array}$ \\
\hline Constant & $\begin{array}{l}-0.027 \\
(0.032)\end{array}$ & $\begin{array}{l}-0.101^{*-* \ldots} \\
(0.039)\end{array}$ & $\begin{array}{l}0.215^{* *} \\
(0.091)\end{array}$ & $\begin{array}{l}0.006 \\
(0.089)\end{array}$ \\
\hline Industry FE & Yes & Yes & Yes & Yes \\
\hline Year FE & Yes & Yes & Yes & Yes \\
\hline Observations & 9859 & 9759 & 9859 & 9759 \\
\hline R-squared & 0.098 & 0.116 & 0.130 & 0.177 \\
\hline
\end{tabular}

* Statistical significance at the $10 \%$ level.

* Statistical significance at the $5 \%$ levels.

** Statistical significance at the $1 \%$ level.

control variables in Eq. (3). The predicted probabilities from the logit model are then used to perform nearest-neighbor propensity score matching procedure (with replacement). This process yields a matched sample of 102 unique firms (54 treated firms and 48 control firms) ${ }^{13}$ To confirm that the matching procedure produces reasonable matches, Panel B of Table 6 presents the summary statistics for the matched sample, separately for the treated and control firms. As is clear, none of the observed differences between the treated firms and control firms is statistically different. In Panel C, we re-estimate Eq. (3) using the matched sample. The interaction term Treated * After obtains a positive coefficient in all the three specifications, which is statistically significant at the 5 percent level when the innovation is measured by the number of citation-weighted patents. This result helps establish the causal link between board independence and innovation.

\section{Board independence and equity-based compensation}

Our empirical analyses so far indicate independent boards encourage managerial risk-taking and hence promote innovation. In this section, we investigate equity-based compensation as a possible tool the boards employ to incentivize risk-taking of managers.

Lerner and Wulf (2007) show that long-term incentives such as stock and option awards are associated with more heavily cited patents. This is consistent with the literature that equity-based compensation is awarded to managers to overcome managerial risk aversion and induce optimal risk-taking behavior (e.g., Smith and Stulz, 1985). Determining the compensation package for executives is part of the board's mission, especially those who are independent, and we expect that boards with more outside directors award their CEOs with more equity-based compensation to induce innovative activities. ${ }^{14}$

We obtain the executive compensation data from the ExecComp database, which provides annual compensation information for chief executive officers (CEOs). To test whether boards with more outside directors behave differently in terms of awarding equity compensation to its CEOs, we run a multiple regression of CEO equity-based compensation on the fraction of outside directors, controlling for CEO/Chairman duality, leverage, market-to-book assets ratio, cash flow, and firm size. We measure equity-based compensation using the value of stock awards and option awards, separately, as a percentage of total compensation for CEOs. ${ }^{15}$ The stock options granted are valued using the Black-Scholes option pricing model. We cluster the standard errors at the firm level to account for the possibility that a firm's equity compensation for its CEOs is serially correlated.

\footnotetext{
${ }^{13}$ Since the matching is done with replacement, some control firms are selected more than once with a treated firm, resulting in slightly fewer control firms in the final matched sample.

${ }^{14}$ Fama and Jensen (1983) argue that compensation decisions should be delegated to outside directors.

15 In ExecComp, the variables for stock awards, option awards, and total compensation are rstlkgmt, option_awards_blk_value, and tdc1. According to the data manual, total compensation ( $\operatorname{tcc} 1$ ) includes salary, bonus, other annual, total value of restricted stock granted, total value of stock options granted (using Black-Scholes), longterm incentive payouts, and all other total.
} 
Results are in Table 7. Columns (1) and (2) report the regression estimates where the dependent variable is the percentage of restricted stocks, and in columns ( 3 ) and (4), the dependent variable is the percentage of stock options. All independent variables are measured with a one-year lag. In column (1), the coefficient on Outdir is positive and statistically significant at the one percent level. All else being equal, boards with more outside directors award more stocks to their CEOs. The magnitude and significance level remain almost unchanged as we add more control variables to the regression, suggesting that our specifications are less likely to suffer from omitted variable bias problem. They also offer more options to their CEOs as shown in column (3) and (4). More interestingly, we find that the magnitude of the coefficient on Outdir is over three folds of those for restricted stocks (3) ( $0.122 \mathrm{vs.}$ 0.040 ). Thus as a board brings in more outside directors, it tends to increase the fraction of equity-based compensation in the CEO's compensation package, and the increase in stock options is much more pronounced than restricted stock. The findings are consistent the literature the equity-based compensation is used to induce risk-taking (e.g., Core and Guay, 1999; Coles et al., 2006), and moreover, options are more effective than stocks to induce risk-taking of CEOs (Sanders and Hambrick, 2007). ${ }^{16}$

\section{Conclusion}

In this paper, we investigate the effect of board independence on firms' innovation. Following recent studies, we measure innovation as the number of patents and citations, and board independence by the fraction of outside directors. Using a sample of public firms from 1996 to 2007, we document a positive relationship between board independence and innovation, indicating board independence in general fosters innovation.

We address the potential endogeneity of board composition by utilizing an exogenous shock to firm's board structure caused by the Sarbanes-Oxley Act as a quasi-natural experiment: in 2003, the NYSE and the NASDAQ issued new listing requirements that mandated a majority of independent directors for all firms listed on the exchanges. Firms previously not compliant with this rule are forced to increase the representation of outside directors, leading to an exogenous increase in board independence. Our empirical framework is a difference-in-difference approach that compares innovative outputs before and after the forced increase in board independence for non-compliant firms, with those that had already had a majority of outside directors in place as a control group. This exercise confirms our main results.

We postulate the observed relationship between board independence and innovation stems from the effect of an effective board on excessive managerial conservatism. Under-diversified managers are reluctant to take risk, creating a suboptimal level of innovation. An independent board can counteract management conservatism by incentivizing risk-taking behavior of managers, and in doing so enhance innovation. Our empirical analysis produces supporting evidence for this conjecture. First, the positive impact of board independence on innovation is concentrated in large firms, firms in traditional industries, firms facing lower product market competitions, and firms with higher financial leverage. These firms are where managers are more likely to be risk averse. In addition, we find that firms with more independent boards provide significantly more equity based compensation to their CEOs. The equity-based compensation encourages the managers to take risk. Overall, our study contributes to the literature by revealing a causal link between board independence and innovation, albeit only for large, traditional firms or firms in noncompetitive industries. These findings have important policy implications as regulators have been increasingly emphasizing on the independence of corporate boards.

When considered together with Balsmeier et al. (2017), our findings seem to indicate the effect of increased board independence on managerial risk-taking varies with the level of risk taken: while independent boards encourage lower-level risk-taking, its disciplinary role could deter managers from taking on projects that are extremely innovative. The innovation ambidexterity literature (e.g., Danneels, 2002; He and Wong, 2004; Jansen et al., 2006) contend that a firm should strike a balance between exploitative and explorative innovation ("ambidexterity"), and the balance depends on the environment it operates in. Our paper does not try to answer the question whether an independent board helps strike the balance, yet it points to the existence of an optimal proportion of outside directors in terms of achieving the innovation ambidexterity-a board full of outsiders may just be as bad as one with too few outsiders.

\section{Appendix A. Variable definitions}

\begin{tabular}{|c|c|c|}
\hline Variables & Definition & Source \\
\hline Patents & number of adjusted patents; see Section 3.1 for details & KPSS Patent database \\
\hline Citations & number of adjusted citations; see Section 3.1 for details & KPSS Patent database \\
\hline Pat_cite & number of citation-weighted patents (Trajtenberg, 1990) & KPSS Patent database \\
\hline Outdir & Fraction of outside directors & RiskMetrics \\
\hline $\mathrm{R} \& \mathrm{D}$ & Research \& Development expenditure & Compustat \\
\hline Leverage & Long-term debt over total assets & Compustat \\
\hline ROA & EBIT divided by total assets & Compustat \\
\hline Tangibility & Net property, plant and equipment divided by total assets & Compustat \\
\hline Capital Expenditure & Capital expenditure divided by total assets & Compustat \\
\hline
\end{tabular}

\footnotetext{
${ }^{16}$ Guthrie et al. (2012) have cautioned that researchers should be aware of severe outliers in CEO compensation data (e.g., Apple and Fossil). We repeated this exercise
} by removing these two outliers from our sample and our results remain qualitatively unchanged. These results are available from the authors upon request. 
Appendix A (continued)

\begin{tabular}{lll}
\hline Variables & Definition & Source \\
\hline Board Size & Number of directors & RiskMetrics \\
CEO Ownership & Percentage of CEO stock ownership & Standard \& Poor's Execucomp \\
Institutional Ownership & Fraction of stocks owned by institutional investors & Compact Disclosure \\
Stock Compensation & Percentage of stock compensation for CEO & Standard \& Poor's Execucomp \\
Option Compensation & Percentage of stock option compensation for CEO & Standard \& Poor's Execucomp \\
Duality & A dummy variable that equals one if CEO and Chairman of the Board are the same person & RiskMetrics \\
Market-to-book & Market value of total assets divided by book value of total assets & Compustat \\
Cash Flow & Cash flow from operating activities & Compustat \\
Total Assets & Total book assets & \\
\hline
\end{tabular}

\section{Appendix B. Board independence and innovation: replace R\&D expenditure with R\&D Capital}

This table reports the pooled OLS (column (1), (2), and (3)) and firm fixed-effects (FE) (column (4), (5), and (6)) regression of innovation on board independence. The sample period is 1996 to 2007 . Innovation is measured by the number of patents that are granted to the firm (Patents), the total number of citations received on the firm's patents (Citations), and the total number of patents weighted by the number of citations received (Pat_cite); all these measures have been adjusted for time effects and patent class effects (see Section 3.1 for more details); board independence is measured by the fraction of outside directors (Outdir). R\&D Capital is cumulative Research \& Development expenditure, calculated as:

$$
\mathrm{R} \& \mathrm{D} \text { Capital }_{i t}=\mathrm{R} \& \mathrm{D}_{i t}+0.8 * \mathrm{R} \& \mathrm{D}_{i t-1}+0.6 * \mathrm{R} \& \mathrm{D}_{i t-2}+0.4 * \mathrm{R} \& \mathrm{D}_{i t-3}+0.2 * \mathrm{R} \& \mathrm{D}_{i t-4}
$$

Leverage is book leverage, measured as long-term debt over total assets; ROA, asset tangibility and capital expenditure are earnings before interest and tax (EBIT), net property, plant and equipment, and capital expenditure, respectively, divided by total assets. Board Size is the number of directors; CEO Stock Ownership is the percentage of stocks owned by CEOs; Institutional Ownership is the percentage of stocks owned by institutional investors. Robust standard errors that are clustered at the firm level are in parenthesis.

\begin{tabular}{|c|c|c|c|c|c|c|}
\hline \multirow[t]{3}{*}{ Variables } & \multicolumn{3}{|l|}{ Pooled OLS } & \multicolumn{3}{|l|}{ Firm fixed-effects } \\
\hline & (1) & (2) & (3) & (4) & (5) & (6) \\
\hline & $\ln (1+$ Patents $)$ & $\ln (1+$ Citations $)$ & $\ln (1+$ Pat_cite $)$ & $\ln (1+$ Patents $)$ & $\ln (1+$ Citations $)$ & $\ln (1+$ Pat_cite $)$ \\
\hline Outdir (\%) & $\begin{array}{l}0.087^{* *} \\
(0.037)\end{array}$ & $\begin{array}{l}0.091^{* *} \\
(0.038)\end{array}$ & $\begin{array}{l}0.134^{* *} \\
(0.054)\end{array}$ & $\begin{array}{l}0.036^{* *} \\
(0.018)\end{array}$ & $\begin{array}{l}0.050^{* * *} \\
(0.021)\end{array}$ & $\begin{array}{l}0.072^{* * *} \\
(0.030)\end{array}$ \\
\hline $\ln (1+R \& D$ Capital $)$ & $\begin{array}{l}0.023^{* * * * * *} \\
(0.003)\end{array}$ & $\begin{array}{l}0.026^{* * * *} \\
(0.004)\end{array}$ & $\begin{array}{l}0.040^{* * * * *} \\
(0.005)\end{array}$ & $\begin{array}{l}-0.007 \\
(0.007)\end{array}$ & $\begin{array}{l}-0.005 \\
(0.005)\end{array}$ & $\begin{array}{l}-0.009 \\
(0.010)\end{array}$ \\
\hline Leverage & $\begin{array}{l}-0.073^{* * *} \\
(0.019)\end{array}$ & $\begin{array}{l}-0.086^{*+*} \\
(0.021)\end{array}$ & $\begin{array}{l}-0.126^{* * * *} \\
(0.031)\end{array}$ & $\begin{array}{l}-0.014 \\
(0.009)\end{array}$ & $\begin{array}{l}-0.008 \\
(0.012)\end{array}$ & $\begin{array}{l}-0.019 \\
(0.017)\end{array}$ \\
\hline ROA & $\begin{array}{l}-0.054 \\
(0.037)\end{array}$ & $\begin{array}{l}-0.029 \\
(0.042)\end{array}$ & $\begin{array}{l}-0.054 \\
(0.058)\end{array}$ & $\begin{array}{l}-0.021 \\
(0.018)\end{array}$ & $\begin{array}{l}-0.031 \\
(0.021)\end{array}$ & $\begin{array}{l}-0.038 \\
(0.028)\end{array}$ \\
\hline Tangibility & $\begin{array}{l}0.036 \\
(0.042)\end{array}$ & $\begin{array}{l}0.020 \\
(0.049)\end{array}$ & $\begin{array}{l}0.048 \\
(0.071)\end{array}$ & $\begin{array}{l}0.040^{* *} \\
(0.020)\end{array}$ & $\begin{array}{l}0.041 \\
(0.027)\end{array}$ & $\begin{array}{l}0.067^{*} \\
(0.037)\end{array}$ \\
\hline Capital Expenditure & $\begin{array}{l}0.203^{*+4} \\
(0.092)\end{array}$ & $\begin{array}{l}0.252^{* *} \\
(0.098)\end{array}$ & $\begin{array}{l}0.339^{+*} \\
(0.142)\end{array}$ & $\begin{array}{l}-0.025 \\
(0.036)\end{array}$ & $\begin{array}{l}0.009 \\
(0.048)\end{array}$ & $\begin{array}{l}-0.014 \\
(0.068)\end{array}$ \\
\hline Board Size & $\begin{array}{l}-0.001 \\
(0.003)\end{array}$ & $\begin{array}{l}-0.000 \\
(0.003)\end{array}$ & $\begin{array}{r}-0.000 \\
(0.004)\end{array}$ & $\begin{array}{l}0.001 \\
(0.002)\end{array}$ & $\begin{array}{l}0.002 \\
(0.002)\end{array}$ & $\begin{array}{l}0.003 \\
(0.003)\end{array}$ \\
\hline CEO Ownership & $\begin{array}{l}0.041 \\
(0.082)\end{array}$ & $\begin{array}{l}0.099 \\
(0.102)\end{array}$ & $\begin{array}{l}0.131 \\
(0.136)\end{array}$ & $\begin{array}{l}-0.125 \\
(0.125)\end{array}$ & $\begin{array}{l}0.004 \\
(0.133)\end{array}$ & $\begin{array}{l}-0.048 \\
(0.182)\end{array}$ \\
\hline Institutional Ownership & $\begin{array}{l}-0.113^{* * *} \\
(0.040)\end{array}$ & $\begin{array}{l}-0.109^{* * * *} \\
(0.040)\end{array}$ & $\begin{array}{l}-0.157^{* * * *} \\
(0.055)\end{array}$ & $\begin{array}{l}0.010 \\
(0.013)\end{array}$ & $\begin{array}{l}0.029^{* *} \\
(0.014)\end{array}$ & $\begin{array}{l}0.032 \\
(0.020)\end{array}$ \\
\hline $\ln$ (Assets) & $\begin{array}{l}0.063^{* * * *} \\
(0.010)\end{array}$ & $\begin{array}{l}0.066^{* * * *} \\
(0.010)\end{array}$ & $\begin{array}{l}0.102^{* * * *} \\
(0.013)\end{array}$ & $\begin{array}{l}0.016^{* * *} \\
(0.006)\end{array}$ & $\begin{array}{l}0.014^{* * *} \\
(0.006)\end{array}$ & $\begin{array}{l}0.025^{* *} \\
(0.010)\end{array}$ \\
\hline Constant & $\begin{array}{l}-0.377^{* * *} \\
(0.081)\end{array}$ & $\begin{array}{l}-0.262^{* * * *} \\
(0.095)\end{array}$ & $\begin{array}{l}-0.481^{* * * *} \\
(0.124)\end{array}$ & $\begin{array}{l}-0.028 \\
(0.045)\end{array}$ & $\begin{array}{l}-0.060 \\
(0.054)\end{array}$ & $\begin{array}{l}-0.075 \\
(0.077)\end{array}$ \\
\hline Industry FE & Yes & Yes & Yes & $\mathrm{N} / \mathrm{A}$ & $\mathrm{N} / \mathrm{A}$ & $\mathrm{N} / \mathrm{A}$ \\
\hline Year FE & Yes & Yes & Yes & Yes & Yes & Yes \\
\hline Observations & 3639 & 3639 & 3639 & 3639 & 3639 & 3639 \\
\hline R-squared & 0.480 & 0.468 & 0.507 & 0.017 & 0.016 & 0.017 \\
\hline
\end{tabular}

* Statistical significance at the $10 \%$ level.

** Statistical significance at the $5 \%$ level.

*** Statistical significance at the $1 \%$ level. 


\section{References}

Adams, R.B., Hermalin, B.E., Weisbach, M.S., 2010. The role of boards of directors in corporate governance: a conceptual framework and survey. J. Econ. Lit 48 (1), $58-107$.

Aghion, P., Van Reenen, J., Zingales, L., 2013. Innovation and institutional ownership. Am. Econ. Rev. 103 (1), $277-304$

Amihud, Y., Lev, B., 1981. Risk reduction as a managerial motive for conglomerate mergers. Bell J. Econ. 12 (2), 605-617.

Atanassov, J., 2013. Do hostile takeovers stifle innovation? Evidence from antitakeover legislation and corporate patenting. J. Financ 68 (3), 1097-1131.

Balsmeier, B., Fleming, L., Manso, G., 2017. Independent boards and innovation. J. Financ. Econ. 123 (3), $536-557$.

Baysinger, B.D., Butler, H.N., 1985. Corporate govemance and the board of directors: performance effects of changes in board composition. J. Law Econ. Org. 1 (1), $101-124$.

Becker-Blease, J.R., 2011. Govetnance and innovation. J. Corp. Finan. 17 (4), 947-958.

Bernile, G., Bhagwat, Y., Yonker, S., 2016. Board diversity, firm risk, and corporate policies. Comell University Working Paper.

Bhagat, S., Black, B., 2001. The non-correlation between board independence and long-term firm performance. J. Corp. Law 27, 231-250.

Brickley, J.A., James, C.M., 1987. The takeover market, corporate board composition, and ownership structure: the case of banking. J. Law Econ. 30 (1), 161-180.

Brisker, E.R., Wang, W., 2016. CEO's Inside Debt and Dynamics of Capital Structure (Available at SSRN).

Brown, J.R., Martinsson, G., Petersen, B.C., 2013. Law, stock markets, and innovation. J. Financ. 68 (4), 1517-1549.

Chhaochharia, V., Grinstein, Y., 2007. Corporate governance and firm value: the impact of the 2002 governance rules. J. Financ. 62 (4), 1789-1825.

Chhaochharia, V., Grinstein, Y., 2009. CEO compensation and board structure. J. Financ. 64 (1), $231-261$.

Coates, J.C., 2007. The goals and promise of the Sarbanes-Oxley Act. J. Econ. Perspect. 21 (1), 91-116.

Coles, Jeffrey L., Daniel, Naveen D., Naveen, Lilitha, 2006. Managerial incentives and rislk-taking. J. Financ. Econ. 79, 431-468.

Coles, J.L., Daniel, N.D., Naveen, L, 2008. Boards: does one size fit all? J. Financ. Econ. 87 (2), 329-356.

Core, J., Guay, W., 1999. The use of equity grants to manager optimal equity incentive levels. J. Account. Econ. 28, $151-184$.

Danneels, E., 2002. The dynamics of product innovation and firm competences. Strateg. Manag. J. 23, 1095-1121.

Duchin, R., Matsusaka, J.G., Ozbas, O., 2010. When are outside directors effective? J. Financ. Econ. 96 (2), $195-214$

Fama, E.F., Jensen, M.C., 1983. Separation of ownership and control. J. Law Econ. 26 (2), 301-325.

Giroud, X., Mueller, H.M., 2010. Does corporate governance matter in competitive industries? J. Financ. Econ. 95 (3), $312-331$.

Gormley, T.A., Matsa, D., 2016. Playing it safe? Managerial preferences, risk, and agency conflicts. J. Financ. Econ. 122 (3), 431-455.

Guthtie, K., Solcolowslcy, J., Wan, K.M., 2012. CEO compensation and board structure revisited. J. Financ 67 (3), $1149-1168$.

Hart, O., 1983. The market mechanism as an incentive scheme. Bell J. Econ. 13, 366-382.

He, Z., Wong, P., 2004. Exploration vs. exploitation: an empirical test of the ambidexterity hypothesis. Organ. Sci. 15 (4), $481-494$.

Hermalin, B.E., Weisbach, M.S., 1991. The effects of board composition and direct incentives on firm performance. Financ. Manag. 20 (4), 101-112

Hermalin, B.E., Weisbach, M.S., 1998. Endogenously chosen boards of directors and their monitoring of the CEO. Am. Econ. Rev. 88 (1), $96-118$.

Hirshleifer, D., Thakor, A.V., 1992. Managerial conservatism, project choice, and debt. Rev. Financ. Stud. 5 (3), 437-470.

Hirshleifer, D., Hsu, P., Li, D., 2013. Innovative efficiency and stock returns. J. Financ. Econ. 107 (3), $632-654$.

Holmstrom, B., 1989. Agency costs and innovation. J. Econ. Behav, Organ. 12 (3), 305-327.

Jansen, J.J., van Den Bosch, F., Volberda, H.W., 2006. Exploratory innovation, exploitative innovation, and performance: effects of organizational antecedents and environmental moderators. Manag. Sci. 51 (11), 1661-1674.

Jensen, M.C., 1993. The modem industrial revolution, exit, and the failure of internal control systems. J. Financ. 48 (3), 831-880.

Jensen, M.C., Meckling, W.H., 1976. Theory of the firm: managerial behavior, agency costs and ownership structure. J. Financ. Econ. 3 (4), 305-360.

Karuna, C., 2007. Industry product market competition and managerial incentives. J. Account. Econ. 43, $275-297$.

Knyazeva, A., Knyazeva, D., Masulis, R.W., 2013. The supply of corporate directors and board independence. Rev. Financ Stud. 26 (6), $1561-1605$.

Kogan, L., Papanikolaou, D., Seru, A., Stoffman, N., 2012. Technological Innovation, Resource Allocation, and Growth (No. w17769). National Bureau of Economic Research.

Lemer, J., Wulf, J., 2007. Innovation and incentives: evidence from corporate R\&D. Rev. Econ. Stat. 89 (4), 634-644.

Loughran, T., Ritter, J.R, 2004. Why has IPO underpricing changed over time? Financ Manag. 33 (3).

Lu, J., Wang, W., 2015. Board independence and corporate investments. Rev. Financ. Econ. 24, 52-64.

Petersen, M.A., 2009. Estimating standard eirors in finance panel data sets: comparing approaches. Rev. Financ Stud. 22 (1), $435-480$.

Romer, P.M., 1990. Endogenous technological change. J. Polit. Econ. 98 (5), S71-S102.

Sanders, W.G., Hambrick, D.C., 2007. Swinging for the fences: the effects of CEO stock options on company risk taking and petformance. Acad. Manag. J. 50 (5), $1055-1078$.

Schwartz-Ziv, M., Weisbach, M.S., 2012. What do boards really do? Evidence from minutes of board meetings. J. Financ. Econ. 108 (2), 349-366.

Segerstrom, P.S., 1991. Innovation, imitation, and economic growth. J. Polit. Econ. 99 (4), 807-827.

Shleifer, A., Vishny, R.W., 1997. A survey of corporate governance. ]. Financ. 52 (2), 737-783.

Smith, C.W., Stulz, R.M., 1985. The determinants of firms' hedging policies. J. Financ. Quant. Anal. 20 (04), $391-405$.

Stigler, G., 1958. The economies of scale. J. Law Econ. 1 (1), 54-71.

Sundheim, D., 2013. Taking Smart Risks: How Sharp Leaders Win When Stakes Are High. McGraw Hill, New York, NY.

Trajtenberg, M., 1990. A penny for your quotes: patent citations and the value of innovations. RAND J. Econ. 21 (1). 172-187.

Wintoki, M.B., Linck, J.S., Netter, J.M., 2012. Endogeneity and the dynamics of internal corporate governance. J. Financ. Econ. 105 (3), 581-606.

Yermack, D., 1996. Higher market valuation of companies with a small board of directors. J. Financ. Econ. 40 (2), 185-211. 